\title{
C2 transpedicular fixation technique in Hangman's Fracture
}

\section{Hangman fraktürlerinde C2 transpediküller fiksasyon tekniği}

\author{
Halil Can Kucukyildiz ${ }^{1}$, Mustafa Karademirr ${ }^{1}$, Giray Güineș ${ }^{1}$ Unal Ozum ${ }^{1}$
}

Cumhuriyet University School of Medicine, Department of Neurosurgery, Sivas, Turkey

Corresponding author: Halil Can Kucukyildiz, MD, Cumhuriyet University School of Medicine, Department of Neurosurgery, Sivas, Turkey

E-mail: drhalilcan@gmail.com

Received/Accepted: August 11,2021 / December 31, 2021

Conflict of interest: There is not a conflict of interest.

\section{SUMMARY}

Objective : Traumatic spondylolisthesis of the axis, also known as hangman fractures, all cervical it accounts for 4-7\% of all traumas and is the second most common axis after odontoid fractures. trauma. There are unstable fractures and the treatment options are immobilization with halo or surgery. is stabilization. By most authors, it is primarily associated with halo in patients with Type 1 and Type 2 fractures.Although external fixation and immobilization are recommended, halon is a difficult orthosis to use.

Because of this, segmental motion sparing surgery provides rapid recovery in suitable patients may be an option. In the case we presented, the treatment approach in Hangman's fractures was reviewed in the literature.

has been reviewed and discussed.

Clinical Presentation: Our case, after AITC, with Levin Edwards Type 1A Hangman fracture, A 40-year-old female patient with no neurological deficits. The patient does not prefer to use a halo orthosis $\mathrm{C} 2$ transpedicular surgery was performed with a lag screw for motion-sparing surgery to a young patient fixation is planned.

Technique: C2 transpedicular lag screw was applied to the patient with intraoperative fluoroscopy.

Conclusion: C2 transpedicular fixation with Lag screw, according to posterior segmental stabilization a more minimally invasive and motionsparing surgery, faster recovery time may be preferred to traditional posterior stabilization methods in selected patient groups due to The patient who did not prefer the use of orthoses due to the social disadvantages of immobilization with Halo it is a quick and cost-effective surgical option in groups with a rapid recovery time.

Keywords: Hangman's fracture, c2 transpedicular fixation, traumatic spondylolistesis of axis.

(D) Halil Can Kucukyildiz
(i) Mustafa Karademir
(i) Giray Güneş
(D) Unal Ozum

ORCID IDs of the authors: H.C.K. 0000-0003-0922-1750 M.K. 0000-0002-0734-9040 G.G. 0000-0003-4610-414X U.O. 0000-0003-2065-2033

\section{ÖZET}

Objective : Aksisin travmatik spondilolistezisi, bilinen diğer adıyla hangman kırıkları, tüm servikal travmaların \%47'sidir ve aksisin, odontoid kırıkları sonrasında görülen en sık ikinci sıradaki travmasıdır. İnstabil kırıklar olup tedavi seçenekleri halo ile immobilizasyon veya cerrahi stabilizasyondur. Çoğu yazar tarafindan Tip 1 ve Tip 2 kırıklı hastalarda öncelikli olarak halo ile eksternal fiksasyon ve immoblizasyon önerilse de, halonun kullanımı zor bir ortez olması sebebiyle, segmental hareket koruyucu cerrahi, uygun hastalarda hızlı iyileşme sağlaması açısından seçenek olabilir. Sunduğumuz olguda, hangman kırıklarında tedavi yaklaşımı literatür gözden geçirilerek tartışılmıştır. 
Clinical Presentation : Vakamız, AİTK sonrası, Levin Edwards Tip 1A Hangman kırığı olan, nörolojik defisiti olmayan 40 yaş kadın hasta. Hastanın halo ortez kullanımı tercih etmemesi sebebiyle, genç yaş hastaya hareket koruyucu cerrahi amacıyla lag vidası ile $\mathrm{C} 2$ transpediküler fiksasyon planlandı.

Technique: Hastaya intraop skopi eşliğinde, c2 transpediküler lag vidası uygulandı.

Conclusion : Lag vidası ile c2 transpediküler fiksasyon, posterior segmental stabilizasyona göre daha minimal invaziv ve hareket koruyucu bir cerrahi olması, iyileşme süresinin daha hızlı olması nedeniyle seçili hasta gruplarında geleneksel posterior stabilizasyon yöntemlerine tercih edilebilir. Halo ile immobilizasyonun sosyal dezavantajları nedeniyle, ortez kullanımını tercih etmeyen hasta gruplarında da iyileşme süresi hızlı ve az maliyetli bir cerrahi seçenektir.

Anahtar sözcükler: Hangman fraktürü, c2 transpediküler fiksasyon, axisin travmatic spondilolistezisi

\section{INTRODUCTION}

Traumatic spondylolisthesis of the axis was first described by Schneider in 1964. Because it resembles severe hyperextension and distractionrelated trauma during hanging it has been called as Hangman fracture ${ }^{1}$. As a result of traffic accidents and falling from a height fractures are usually caused by hyperextension and axial loading, spinal cord is not exposed to the distraction force, neurological deficits are usually not observed in these patients ${ }^{2}$. It is $4-7 \%$ of all cervical fractures and is the second most common trauma to the axis after odontoid fractures ${ }^{3}$. Hangman fractures are generally classified according to Effendi and Levine and Edwards classifications, which is modified for of Effendi classification ${ }^{2,4}$.

The first comprehensive classification of Hangman fractures was made by Effendi. According to the injury mechanism; hyperextension with axial loading was classified as Type 1, those caused by hyperextension and rebound flexion mechanism as Type 2, and those with flexion and rebound extension as Type $3^{2}$. Levine and Edwards (LE) added Type $2 \mathrm{~A}$ formed by flexion and distraction mechanism to the Effendi classification and Type $1 \mathrm{~A}$ as an atypical hangman fracture ${ }^{4}$. In type $1 \mathrm{~A}$ fractures, the fracture lines on both sides are not parallel and the fracture on one side runs along the foramen transversium. Type 1 fractures (displacement $<3 \mathrm{~m}$ ) are usually treated conservatively. Type 3 fractures with C 2-3 subluxation require $\mathrm{C} \quad 2-3$ fusion. Type 2 (displacement> $3 \mathrm{~mm}$ ) and Type 2a fractures treatment options vary ${ }^{5,6}$.
Direct pedicular fixation of $\mathrm{C} 2$ was first described by Leconte ${ }^{7}$. Transpedicular fixation of $\mathrm{C} 2$ in Hangman fractures is defined as a physiological surgical approach because it preserves normal segmental motion ${ }^{8}$.

\section{CASE}

A 40-year-old female patient who was taken into emergency surgery due to splenic laceration in our hospital after an in-vehicle traffic accident, while being followed up in the intensive care unit on the 1 st postoperative day, we were consulted with the description of severe pain during neck movements and limitation of neck movements. In the evaluated cervical computed tomography (CT) of the patient, bilateral C2 pars interarticularis fracture compatible with LE Type 1A was observed (Figure 1). Cervical magnetic resonance imaging (MRI) was planned for the patient. Traumatic disc herniation, C2-3 disc rupture, C2-3 facet joint pathology and posterior ligamentous damage were not observed in the cervical MRI (Figure 2).

The patient had no deficits in her neurological examination. The patient's preoperative Japon Orthopedic Association (JOA) score was 18, and isual analogue scale (VAS) score was $8^{8,9}$. She was informed about external halo immoblization and surgical options as conservative treatment options. C2 transpedicular fixation with lag screw was planned for the patient who preferred surgical treatment for motion-preserving surgery.

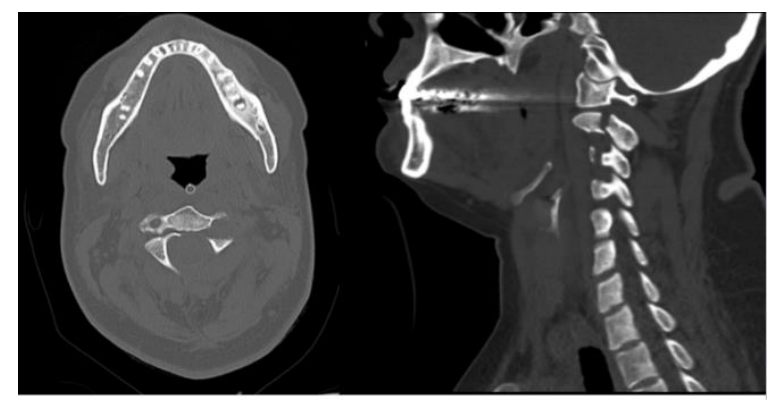

Figure 1: Bilateral pars interarticularis fracture compatible with Levine Edwards Type 1A Fracture 


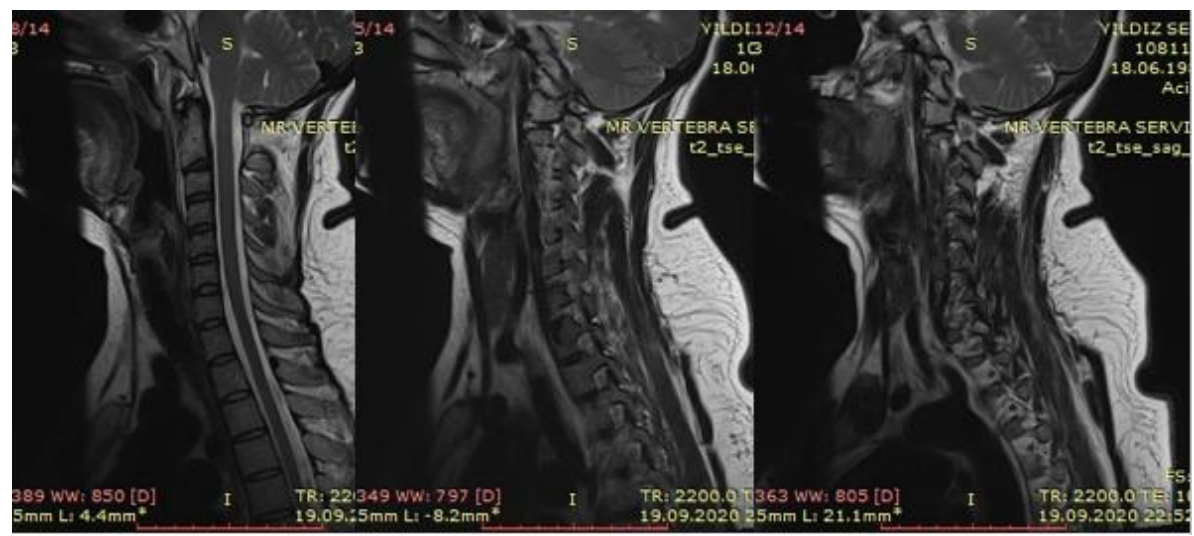

Figure 2: In the preoperative MR evaluation, traumatic disc herniation, $\mathrm{C} 2-3$ disc rupture, dislocation in the C2-3 facet joints and o damage was observed in posterior ligamentous structures.

\section{MATHERIAL AND METHODS}

After the Mayfield headgear was attached, the patient was placed in the prone position with the Philadelphia type collar attached. After the collar was removed, Mayfield was fixed on the table by applying slight flexion and traction to the head. Cervical alignment was checked with $\mathrm{C}$ arm fluoroscopy. The skin incision was made from the midline from the occipital protuberance to the $\mathrm{C} 4$ vertebra. At $\mathrm{C} 1$ vertebra level to prevent vertebral artery damage, dissection more than $1.5 \mathrm{~cm}$ from the midline to lateral was avoided. During dissection of the paravertebral muscles attached to the $\mathrm{C} 2$ and $\mathrm{C} 3$ vertebrae, damage to the $\mathrm{C} 2-3$ facet joint capsule, which was observed intraoperatively intact, was avoided. The lateral borders of the inferior articular process were exposed at the $\mathrm{C} 2$ vertebra level. The upper surface of the $\mathrm{C} 2$ pedicle was exposed by dissecting the atlantoaxial membrane. It was drilled from the upper medial quadrant of the inferior articular process by angling approximately 20 degrees to the cranial and approximately 20 degrees to the medial with a craniotome. It was observed that the $\mathrm{C} 2$ corpus was reduced by sending the lag screws with fluoroscopy, and vertebra alignment was checked with fluoroscopy. The patient was awakened with the philedelphia collar on. There was no postoperative neurological deficit. Control imaging was performed with postoperative cervical CT. (Figure 3). Bilateral vertebral arteries were found to be intact. (Fig3.a). The patient's postop JOA score was 18 . The patient was discharged on the 7 th postoperative day, with sutures removed. She was followed up with a Philadelphia collar for 1 month. Cervical CT control was performed at the end of the first month. On cervical CT, union development was observed in the $\mathrm{C} 2$ vertebral fracture. (Figure 4) Minimal angulation and kyphosis were observed in C2-3. (Figure 5) The patient, who did not use the Philadelphia collar effectively, was recommended to be followed up with a Philedelphia collar for 1 more month. No increase in kyphosis was observed in the postoperative 2nd month control. Neurological deficit was not observed. Provided fusion, no limitation in neck range of motion, Additional surgery for segmental stabilization was not planned for the patient, who did not have an increase in kyphosis. The patient's postop second month VAS score was 2.

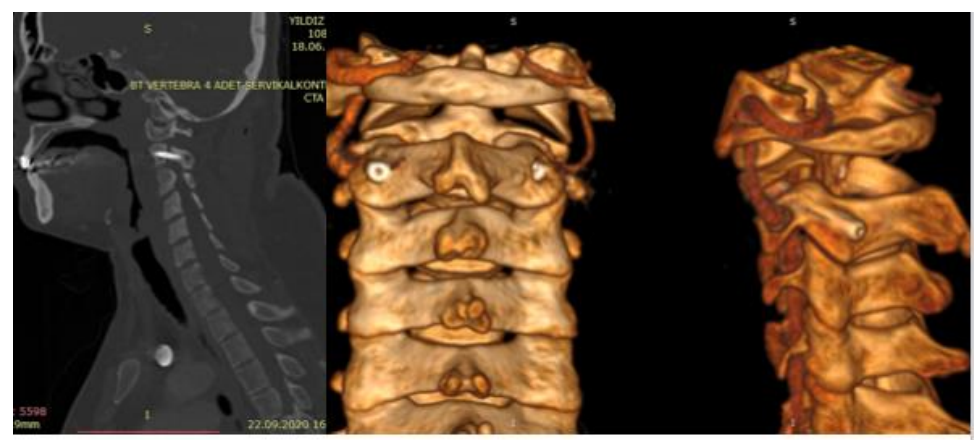

Figure 3: Postoperative bilateral vertebral arteries were found to be intact. 


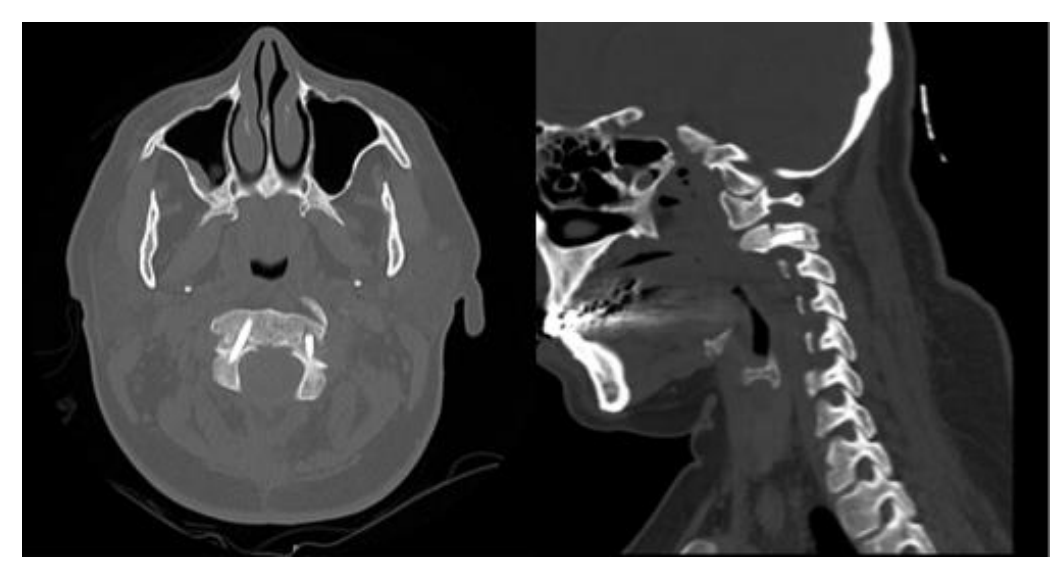

Figure 4: Union development was observed in the cervical CT performed in the 1st month postoperatively.

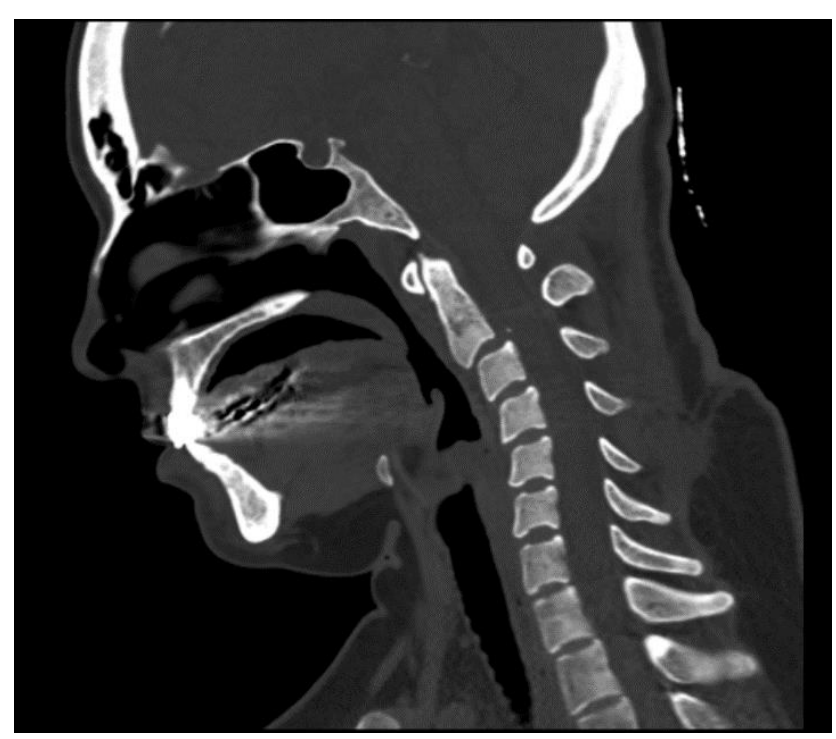

Figure 5: Angulation in C2-3, kyphosis seen in postoperative 2nd month control

\section{DISCUSSION}

The optimal treatment method in Hangman fractures is still controversial. Effendi et al. Stated that they treated patients with Type 1 fractures by external immobilization, while they reported that they treated $50 \%$ of patients with Type 2 fractures conservatively. Hawkins suggested that patients with Hangman fractures should primarily be applied halo, and surgery should be performed in the long-term non-fusion group. Levine and Edwards reported that they treated patients with Type 1, Type 2 and Type 2A non-surgical methods in their series ${ }^{4}$.

In many cases in the literature, Type 1 and Type 2 Hangman fractures have been accepted as stable and conservative treatment has been preferred by the authors. However, due to the disadvantages of external immobilization with halo brace, motion- preserving, minimally invasive surgical approaches are considered as a reasonable option for such fractures.

In a retrospective study conducted by Vaccaro et al in which Type 2 and Type 2A fractures were followed with halo brace, union developed in 21 of 27 Type 2 fractures and in all 4 patients with Type $2 \mathrm{~A}$ fractures during follow-up with halo brace. ${ }^{1}$

However, the need for long-term use of halo brace is one of the disadvantages of conservative treatment, as it is difficult for patients who use halo brace to return to their daily life socially and it causes long-term loss of workforce. After surgical treatment, the recovery period is short, labor loss is less and it is easier for them to return to social life. 12 
In the studies in the literature, nonunion and anterior instability were reported in $60 \%$ of cases where Type 2 and Type $2 \mathrm{~A}$ fractures were treated conservatively. ${ }^{13}$

In Hangman fractures, general surgical approaches are C2-3 anterior plate, screw fixation, $\mathrm{C} 1-2$ or C23 posterior segmental fixation, or $\mathrm{C} 1-2-3$ posterior fixation. ${ }^{5,6}$

Although C2-3 anterior plate screw fixation is the preferred approach in cases with $\mathrm{C} 2-3$ traumatic disc herniation, it is a biomechanically poor technique compared to posterior fixation techniques. [5.13] When posterior fixation is performed with $\mathrm{C} 1-\mathrm{C} 2, \mathrm{C} 2-3, \mathrm{C} 1-\mathrm{C} 2-\mathrm{C} 3$ screws, the range of motion of the stabilized segments cannot be preserved. ${ }^{13}$

Direct pedicular fixation of $\mathrm{C} 2$ was first defined by Leconte. ${ }^{7}$ Transpedicular fixation of $\mathrm{C} 2$ in Hangman fractures is defined as a physiological surgical approach because of its preservation of normal segmental movement. ${ }^{8,14}$

In addition, $\mathrm{C} 2$ corpus reduction cannot be achieved with standard pedicle screws. Allowing reduction of the corpus in fixation with a pedicular lag screw through the bilateral pars articularis fracture line increases the union. ${ }^{8,14}$

Borne et al. Reported that direct pedicular screw fixation was a simple, safe, anatomically and functionally good method in 18 patients with $\mathrm{C} 2$ pedicular fractures. ${ }^{8}$ Muller et al. Used this technique in 5 of 15 patients with Type II fractures and followed the patients with a collar for 5-8 weeks postoperatively and reported good results ${ }^{15}$. Verheggen et al. Reported good results in 13 patients with Type II and Type IIA fractures treated with pedicular screw fixation and a postop collar. 17

In a study published by Liu et al, in which 25 patients were included and followed up for two years postoperatively, C2 transpedicular fixation with lag screw was an effective, simple and lowcost treatment method in the surgical treatment of Type 1, Type 2 and Type 2A fractures and They reported that there was no loss of range of motion.

The greatest risk identified for this technique in the literature is vertebral artery damage and direct screw penetration into the vertebral canal. ${ }^{17,18}$ Vertebral artery and $\mathrm{C} 2$ pedicle anatomy should be well known.

In our case, although there was no damage to the C2-3 facet joint pathology / facet dislocation and posterior ligamentous structures secondary to the trauma detected in the patient on preoperative MRI and intraoperative observation, minimal angulation and kyphosis were observed in the cervical CT performed at the postop 1st month control. The reason for this may be that the patient does not use the Philadelphia collar effectively.

In the literature, permanent instability has been shown in Type II fractures with translation more than (> $4.5 \mathrm{~mm})$, which may be due to discoligamentous injury that could not be determined in C2-C3 before surgery ${ }^{19}$ In cases with C2-3 facet dislocation, facet joint capsule damage and posterior ligamentous damage at this level, C2-3 posterior stabilization may be a more secure option to prevent kyphotic deformity. ${ }^{19}$ However, since the reduction of the $\mathrm{C} 2$ corpus cannot be achieved with standard pedicle screws, union does not develop in the early period and the external imbolization period of the patient is prolonged in the postoperative period.

Our recommendation; In cases where this type of kyphotic deformity is thought to develop, if the lag screws are designed in a suitable format to allow segmental posterior stabilization with rod compatibility, both C2-3 stabilization and pedicle fixation and corpus reduction from the fracture line can be performed in the same session.

\section{CONCLUSION}

Although Type 1 and Type 2 fractures are accepted as stable in the literature and conservative methods are recommended as the primary approach in treatment, immobilization with halo brace is difficult to use for the patient and has disadvantages. The prolonged treatment process makes it difficult for the patient to return to social life and causes serious labor loss in young patients. Pedicle fixation with $\mathrm{C} 2$ lag screw stands out as a more physiological and preserving surgery than other segmental stabilization options. In selected patient groups that require $\mathrm{C} 2-3$ segmental stabilization, if the lag screws are designed in a design that allows segmental posterior stabilization with the rod, C2-3 stabilization is performed in cases where kyphotic deformity may develop, and pedicle fixation and corpus reduction from the fracture line are performed in the same session. and recovery time can be accelerated.

\section{REFERENCES}

1. Schneider RC, Livingston KE, Cave AJ, et al. "Hangman's fracture" of the cervical spine. J Neurosurg. 1965;22:141-154.

2. Effendi B, Roy D, Cornish B, Dussault RG, Laurin CA: Fractures of the ring of the axis: A 
classification based on the analysis of 131 cases. J Bone Joint Surg Br 63B:319-327, 1981

3. Murphy H, Schroeder GD, Shi WJ, Kepler CK, Kurd MF, Fleischman AN, et al. Management of Hangman's fractures: a systematic review. J Orthop Trauma 2017;31(Suppl 4):S90-5.

4. Levine AM, Edwards CC: The management of traumatic spondylolisthesis of the axis. J Bone Joint Surg Am 67A:217-226, 1985

5. X.F. Li, L.Y. Dai, H. Lu, X.D. Chen, A systematic review of the management of hangman's fractures, Eur. Spine J. 15 (3) (2006) 257-269.

6. J.J. Shin, S.H. Kim, Y.E. Cho, S.H. Cheshier, J. Park, Primary surgical management by reduction and fixation of unstable hangman's fractures with discoligamentous instability or combined fractures: clinical article, J. Neurosurg. Spine 19 (5) (2013) 569-575.

7. Leconte P. Fracture et luxation des deux premières vertèbres cervicales. In: Judet $\mathrm{R}$, editor. Luxation Congenénitale de la Hanche: Fractures du Cou-de-pied Rachis Cervical. Actualités de Chirurgie Orthopédique de 1'Hö pital Raymond-Poincaré. Paris: Masson et Cie; 1964. pp. 147-166

8. Benzel EC, Lancon J, Kesterson L, et al. Cervical laminectomy and dentate ligament section for cervical spondylotic myelopathy. J Spinal Disord 1991; 4:286-95.

9. Wewers ME, Lowe NK. A critical review of visual analogue scales in the measurement of clinical phenomena. Research in Nursing \& Health 13: 227-236, 1990.

10. Borne GM, Bedou GL, Pinaudeau M. Treatment of pedicular fractures of the axis. A clinical study and screw fixation technique. J Neurosurg. 1984;60:88-93. doi: 10.3171/jns. 1984.60.1.0088.

11. Vaccaro AR, Madigan L, Bauerle WB, Blescia A, Cotler JM. Early halo immobilization of displaced traumatic spondylolisthesis of the axis. Spine. 2002;27(20):2229-2233. doi: 10.1097/00007632-200210150-00009.

12. Özer AF, Çerçi A, Sasani M, Kalelioğlu M, Sarığlu AÇ, Posterior screw-plate fixation in traumatic spondylolisthesis of axis, Turkish Journal Of Trauma and Emergency Surgery. (1999); 5(4): 288-291

13. ElMiligui Y, Koptan W, Emran I. Transpedicular screw fixation for type II Hangman's fracture: a motion preserving procedure. Eur Spine J. 2010;19(8):1299-1305. doi:10.1007/s00586-010-1401-

14. Liu, Y., Zhu, Y., Li, X. et al. A new transpedicular lag screw fixation for treatment of unstable Hangman's fracture: a minimum 2year follow-up study. J Orthop Surg Res 15, 372 (2020). https://doi.org/10.1186/s13018-02001911-3

15. Muller EJ, Wick M, Muhr G. Traumatic spondylolisthesis of the axis: treatment rationale based on the stability of the different fracture types. Eur Spine J. 2000;9:123-128. doi: $10.1007 / \mathrm{s} 005860050222$.

16. Verheggen R, Jansen J. Hangman's fracture: arguments in favor of surgical therapy for type II and III according to Edwards and Levine. Surg Neurol. 1998;49(3):253-261. doi: 10.1016/S0090-3019(97)00300-5.

17. Rajasekaran S, Vidyadhara S, Shetty AP. IsoC3D fluoroscopy-based navigation in direct pedicle screw fixation of Hangman fracture: a case report. J Spinal Disord Tech. 2007;20(8):616-619. doi: 10.1097/BSD.0b013e318074f978.

18. Roy-Camille R, Saillant G, Mazel C. Internal fixation of the unstable cervical spine by a posterior osteosynthesis with plats and screws. In: The Cervical Spine Research Society, editor. The cervical spine. 2. Philadelphia: Lippincott Williams \& Wilkins; 1989. pp. 390-403.

19. Salunke P, Sahoo SK, Krishnan P, Chaterjee D, Sodhi HB. Are C2 pars-pedicle screws alonefor type II Hangman's fracture overrated? Clin Neurol Neurosurg 2016;141:7-12. 